\title{
Suppression of Phytophthora Blight in Bell Pepper by a No-Till Wheat Cover Crop
}

\author{
Jean B. Ristaino, Gregory Parra, and C. Lee Campbell
}

Department of Plant Pathology, North Carolina State University, Raleigh, 27695-7616.

Accepted for publication 13 December 1996.

\begin{abstract}
Ristaino, J. B., Parra, G., and Campbell, C. L. 1997. Suppression of Phytophthora blight in bell pepper by a no-till wheat cover crop. Phytopathology 87:242-249.

Four mechanisms of dispersal of propagules of Phytophthora capsici were investigated through modifications in cultural practices and fungicide applications in field plots of bell pepper (Capsicum annиum). Dispersal of soil inoculum was suppressed, and final incidence of disease was 2.5 to $43 \%$ when stubble from a fall-sown, no-till, wheat cover crop was present. Final disease incidence was 71 to $72 \%$ and pathogen spread

placed on the surface served as the source of initial inoculum. The fungicide metalaxyl applied in the irrigation system did not suppress withinrow spread of surface inoculum from a sporulating fruit on plastic, but did limit across-row spread; final disease incidence in metalaxyl-treated plots was 11.5 to $14 \%$. Pathogen dispersal mechanisms were modified most dramatically by the no-till cropping system. Thus, simple changes in cultural practices can have dramatic effects on the development of Phytophthora epidemics. Ecologically based disease management strategies have the potential to reduce our reliance on agrichemicals in this and similar pathosystems.
\end{abstract} occurred within and across rows when all dispersal mechanisms were operative in plots of pepper planted into bare soil. Final disease incidence was 42 to $78 \%$ with black plastic mulch when a sporulating pepper fruit
Additional keywords: epidemiology, sustainable agriculture.
Diseases caused by soilborne, oomyceteous pathogens in the genus Phytophthora are responsible for significant economic losses on important crops worldwide $(10,14)$. Traditionally, fungicides and resistant cultivars have been used to manage these diseases in the field. Fungi in the genus Phytophthora frequently develop virulent races that can overcome single-gene resistance in host plants $(31,32)$, and insensitivity to phenylamide fungicides such as metalaxyl has occurred in commercial fields $(10,17)$. The lack of information on the spatial dynamics of inoculum dispersal of soilborne pathogens and disease development has hindered our ability to develop sustainable management strategies for Phytophthora diseases. There is a need to develop strategies for disease management on crops that reduce our reliance on agrichemicals, produce fewer residues, preserve the host resistance available and are, thus, more sustainable in the long term $(2,3)$.

The pepper (Capsicum annuum)-Phytophthora capsici pathosystem is more complex than most other Phytophthora pathosystems in that virtually every part of the host plant can be infected (25). P capsici can spread by at least four distinct mechanisms. These mechanisms of dispersal include the following: mechanism 1 , movement from root to root down rows either by root growth to inoculum, inoculum movement to roots, or root-to-root contact $(8,25,28)$; mechanism 2 , inoculum spread in surface water $(6,7$, $18,21,22,23,27,28)$; mechanism 3, splash dispersal from soil to leaves, stems, or fruit $(19,20,21)$; and mechanism 4 , aerial dispersal from sporulating lesions on leaves, stems, or fruit (11). Thus, Phytophthora blight is not strictly a fruit, foliar, stem, or root disease, and the pathogen is not exclusively airborne, waterborne, or soilborne.

Black plastic mulch is used commonly in commercial vegetable production systems and was used in our study as one means of

Corresponding author: J. B. Ristaino; E-mail address: Jean_Ristaino@ncsu.edu

Publication no. P-1997-0131-03R

(C) 1997 The American Phytopathological Society affecting inoculum dispersal. Black plastic can potentially (i) act as a barrier to dispersal of sources of soilborne inoculum to aerial portions of plants (interferes with dispersal mechanisms 3 and 4); (ii) increase splash dispersal of surface-resident sources of inoculum on plastic to aerial parts of the plant (15) (dispersal mechanism 3); and (iii) enhance dispersal of inoculum in free water on the plastic surface down the plant row (dispersal mechanism 2) (6). In contrast, the presence of wheat stubble and straw mulch may increase the incidence of root infections because of increased soil moisture, but will reduce the level of splash dispersal of soil inoculum and subsequent aerial infections (15) (interferes with dispersal mechanisms 3 and 4). The systemic fungicide metalaxyl is effective against $P$. capsici and should reduce root disease and foliar infections caused by $P$. capsici (interferes with dispersal mechanisms 1, 2, 3, and 4).

In the first portion of our research $(13,24,25)$, we characterized the dynamics of spatial patterns of disease caused by naturally occurring inoculum of $P$. capsici in seven commercial pepper fields over time and identified the primary mechanisms of inoculum dispersal $(13,24,25)$. The pathogen was dispersed primarily by movement from root to root down rows (dispersal mechanism 1) and by surface water (dispersal mechanism 2). Limited splash dispersal (dispersal mechanism 3) was observed late in the epidemic, and no aerial dispersal (dispersal mechanism 4) was observed. Our objectives in this work were to modify the pathosystem by means of cultural and chemical management strategies to permit specific inoculum dispersal mechanisms to operate in artificially infested pepper fields and to determine the subsequent impact on specific spatial and temporal components of epidemic development. A preliminary report on a portion of this work has been published (26).

\section{MATERIALS AND METHODS}

Inoculum production. Fungal inoculum for use in field experiments was prepared by culturing $P$. capsici at $25^{\circ} \mathrm{C}$ for 4 
weeks in $500 \mathrm{~cm}^{3}$ of vermiculite amended with $250 \mathrm{ml}$ of $\mathrm{V}-8$ broth ( $800 \mathrm{ml}$ of water, $200 \mathrm{ml}$ of $\mathrm{V}-8$ juice, and $2 \mathrm{~g}$ of $\left.\mathrm{CaCO}_{3}\right)$ in 1-liter jars. Inoculum consisted of hyphae and sporangia of the fungus. An equal mixture of two isolates of $P$. capsici (B1HB14 [A1 mating type] and B2HH4 [A2 mating type]), both pathogenic to pepper, was used to infest soil in field plots and inoculate fruit.

Field plots. Treatments were imposed under field conditions designed to favor the four different mechanisms of inoculum dispersal. In 1993, experiments were conducted in artificially infested plots that did not initially contain the pathogen. In 1994, experiments were repeated in different plots that also did not initially contain the pathogen. An experimental unit consisted of eight double-row beds prepared on 1.5-m centers with row lengths of $9.1 \mathrm{~m}$. Three different surface treatments were imposed. Initially, all plots were covered with black plastic mulch and fumigated with methyl bromide-chloropicrin $(392 \mathrm{~kg} / \mathrm{Ha})$ in the fall to eliminate pathogen inoculum. After fumigation, plastic was removed from one treatment (treatment 2) and a winter wheat cover crop was sown in the fall. In the spring, wheat was killed with paraquat, and the residue was mowed prior to planting. Straw mulch and stubble were left in the furrows and on the plant rows. Plastic mulch was removed from another treatment in the spring for bare soil plots (treatment 1). Plastic mulch was left on the remaining plots for the duration of the experiment (treatments 3 to 8). All plots were planted with 8-week-old pepper plants (cv. Jupiter) in early May, and within-row plant spacing was $30 \mathrm{~cm}$.

Inoculum was introduced into plots at one end of rows 4 and 5 of the eight double-row plots by one of three methods: soil inoculum in the row, a point source of sporangial and mycelial inoculum (mixture of $500 \mathrm{~cm}^{3}$ of two isolates of the opposite mating type) of $P$. capsici grown in V-8 vermiculite medium was buried approximately $10 \mathrm{~cm}$ below the soil surface in the transplant hole of one plant; soil inoculum in the furrow, inoculum was buried in the furrows adjacent to each of rows 4 and 5; or surface fruit inoculum, a pepper fruit on which the fungus was sporulating was placed on the top of the soil surface to favor splash dispersal of inoculum to leaves, stems, and fruit. The following eight treatments were included: treatment 1 , bare soil in plots plus soil inoculum; treatment 2, no-till wheat mulch plus soil inoculum in the row (interferes with dispersal mechanisms 2, 3, and 4); treatment 3 , plastic mulch over soil inoculum in the row (interferes with dispersal mechanisms 3 and 4); treatment 4, plastic mulch plus surface fruit inoculum (interferes with dispersal mechanism 1); treatment 5, plastic mulch plus soil inoculum in the furrow (interferes with dispersal mechanisms 1, 3, and 4); treatment 6 , plastic mulch plus surface fruit inoculum and metalaxyl fungicide applied through the irrigation system (interferes with dispersal mechanisms 1, 2, 3, and 4); treatment 7, plastic mulch and no inoculum; and treatment 8 , plastic mulch over soil inoculum and no irrigation (interferes with dispersal mechanisms 1 [zoospore movement to roots], 3, and 4). The fungicide metalaxyl (Ridomil 2E) was applied in treatment 6 through the irrigation system at a rate of 4.7 liters per hectare at transplanting and at 30 and 60 days after transplanting. All irrigated plots were watered twice weekly with a drip system. Each eight-double-row experimental unit was surrounded by a 9.1-m border of soybean (cv. Delta Pine) to minimize interplot interference. Raised beds (20 $\mathrm{cm}$ high and $1.5 \mathrm{~m}$ wide) were placed at the head and foot of each plot to prevent drainage water from entering adjacent plots. Each of the eight treatments were replicated three times in the field in a randomized complete block design.

Disease assessment and yield. Proportions of wilted plants; plants with crown lesions, stem lesions, leaf lesions, and fruit lesions; and dead plants were assessed. These spatially referenced, disease symptom data were recorded on a per plant basis in each row 12 to 17 times each growing season. The relative importance of the different mechanisms of dispersal of inoculum to epidemic development was determined by calculating effects of the cultural and chemical treatments on changes in disease over time. Repeated measures analysis of variance (SAS Institute, Cary, NC) was used for analysis of data recorded over time. Tests of the effect of time and time $\times$ treatment interactions were performed with Wilks' lambda, a likelihood ratio test statistic for multivariate analysis of variance. Disease progress curves were plotted, and data in the figures represent the mean disease incidence at a given time averaged over the three replications of each treatment. Spatial pattern maps for final disease incidence were plotted individually for each treatment replication combination. A representative spatial map from one of the three replications for data from 1993 is shown.
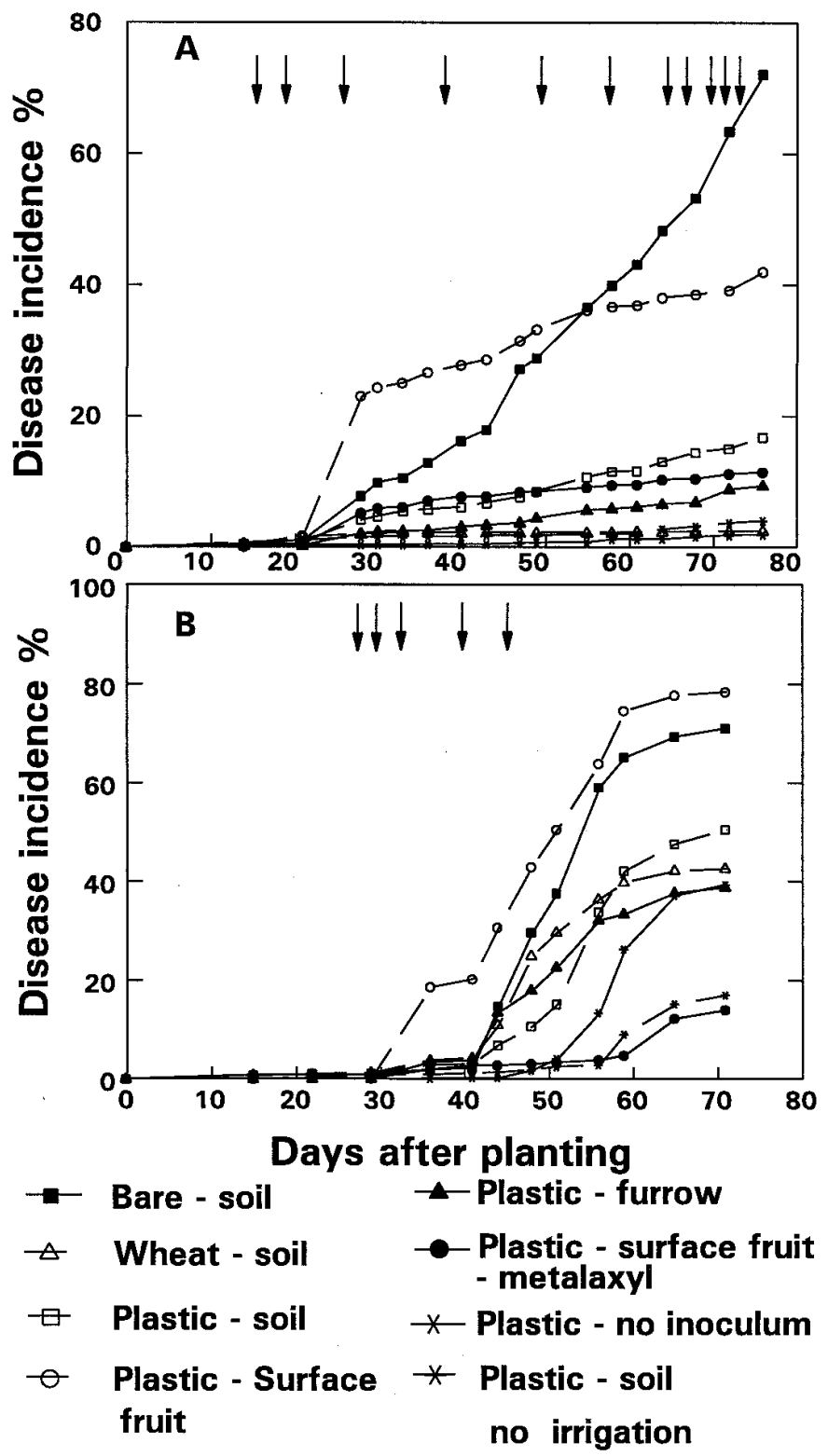

Fig. 1. Progression of Phytophthora epidemics caused by the soilborne fungus Phytophthora capsici in 1993 in artificially infested plots as affected by cultural and chemical control strategies. A, Incidence of total disease in 1993. B, Incidence of total disease in 1994. Plants were planted into bare soil, wheat stubble, or black plastic. Three methods of inoculation included soil in the row for which inoculum of $P$. capsici was buried approximately 10 $\mathrm{cm}$ below the soil surface in rows 4 and 5 of eight-double-row plots in the transplant hole; soil in the furrow for which inoculum was buried in the furrows adjacent to each of rows 4 and 5; or surface fruit (a sporulating pepper fruit) was placed on the soil surface. Arrows indicate rainfall events greater than $1.27 \mathrm{~cm}$. 
Yield was measured in multiple harvests by row in each treatment at the end of the season. Fresh weights of fruits in various size categories and cull fruits were measured. The total harvestable yield was calculated. Yield data were analyzed by analysis of variance with treatment, replication, and row effects in the model.

Inoculum quantification in soil. Inoculum of $P$. capsici in soil was assayed immediately after inoculation, midseason, and at harvest. At the first sample time, one soil core $(1.9 \mathrm{~cm}$ diameter $\times$ $20 \mathrm{~cm}$ deep) was removed from each side of the plot approximately $20 \mathrm{~cm}$ from the plant row at the site of inoculation and 3, 6 , and $9 \mathrm{~m}$ down rows 4 and 5 . At the second sample time, rows 3 , 4,5 , and 6 were sampled, whereas, at the final sample time, all rows were sampled at the same four locations in each plot. Soil

TABLE 1. Repeated measures analysis of variance describing effects of surface mulch and inoculum treatment on the final incidence of Phytophthora blight on bell pepper in 1993 and 1994

\begin{tabular}{lll}
\hline & \multicolumn{2}{c}{ Probability $^{\mathrm{a}}$} \\
\cline { 2 - 3 } Source of variation & 1993 & 1994 \\
\hline Time & 0.001 & 0.001 \\
Time $\times$ block & 0.1371 & 0.027 \\
Time $\times$ treatment & 0.001 & 0.0009 \\
\hline
\end{tabular}

a Tests of effects of time and time $\times$ treatment interactions were performed with Wilks' lambda, which is a likelihood ratio test statistic for multivariate analysis.
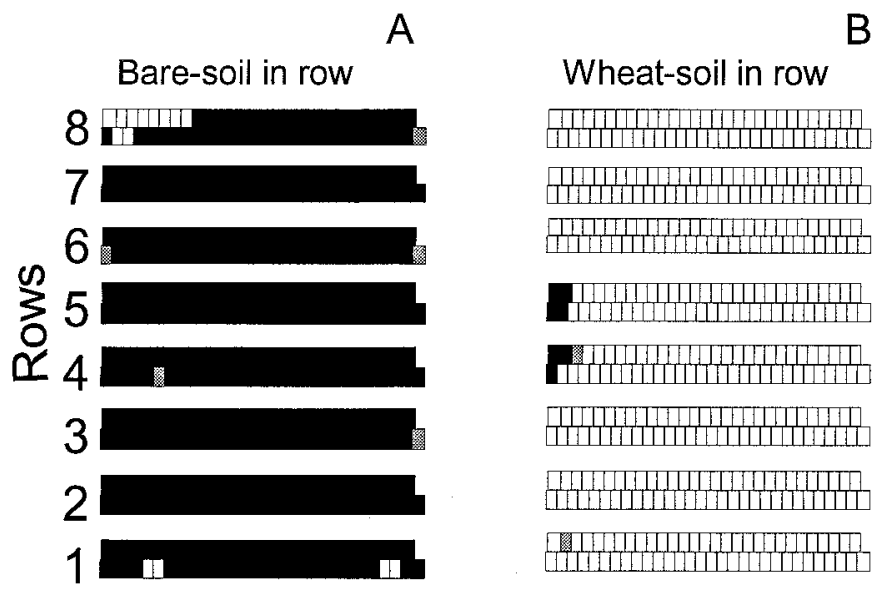

B
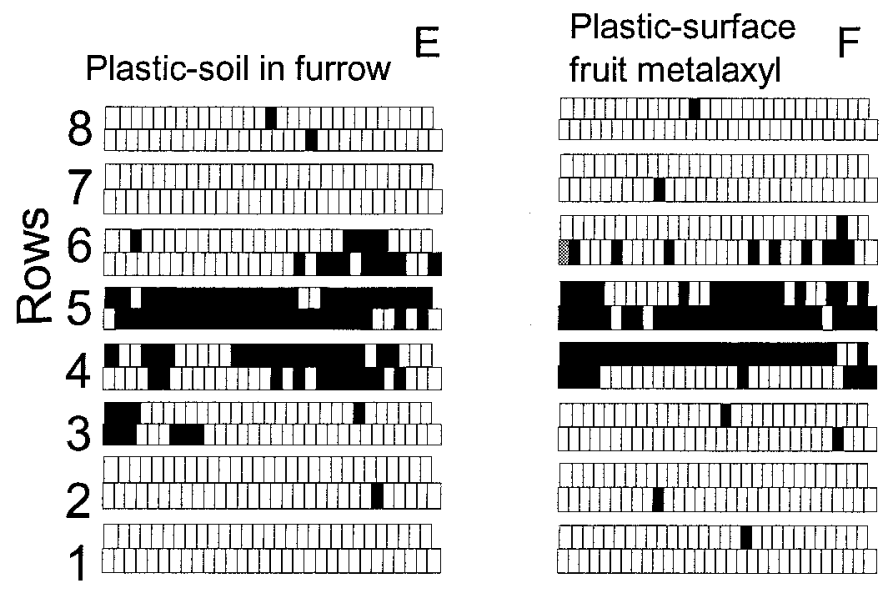

A

E was placed in plastic bags, held at room temperature, and assayed within 2 days of sampling. Soil from initially infested sites was diluted either $1: 100$ or $1: 50$ in $0.25 \%$ water agar; lesser dilutions of $1: 5$ or 1:2 were used with soil sampled from other locations down the row. From each dilution, a 1-ml sample was spread onto Masago's medium (16) amended with hymexazol at $20 \mu \mathrm{g} / \mathrm{ml}$ (99.5\% a.i. Tachigaren; Sankyo Co., Ltd., Tokyo) in each of five petri dishes. Dishes were incubated at $25^{\circ} \mathrm{C}$ in the dark for 48 to $72 \mathrm{~h}$, rinsed with water, and colonies of $P$. capsici were counted. Gravimetric water content of soil samples at each location was calculated. Inoculum density was defined as the number of CFUs per gram of dry soil.

Rainfall data were recorded with tipping-bucket rain gauges (Campbell Scientific Inc., Logan, UT). Wind speed and direction were monitored with anemometers and wind vanes, respectively, attached to a CR-21X micrologger (Campbell Scientific Inc.) at each field location.

\section{RESULTS}

Planting pepper into stubble from a no-till wheat cover crop suppressed $(P<0.001)$ spread of $P$. capsici in both years (Fig. 1). Final disease incidence was $2.5 \%$ in 1993 when surface water, and splash and aerial dispersal were suppressed via the cover crop of wheat (Fig. 1A). In fact, pathogen spread did not occur from the initial point of infestation in rows 4 and 5 in plots with the wheat

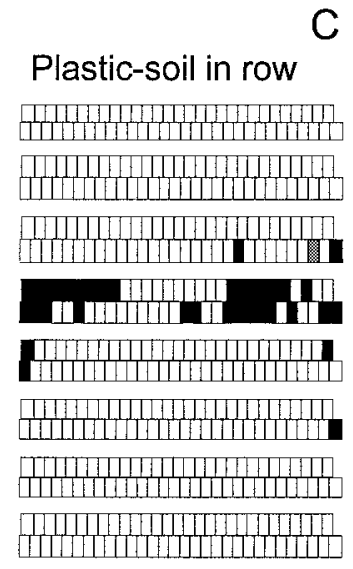

C

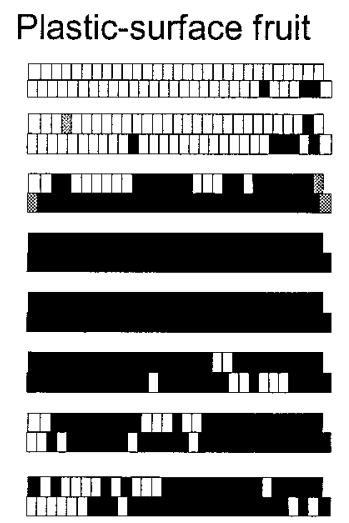

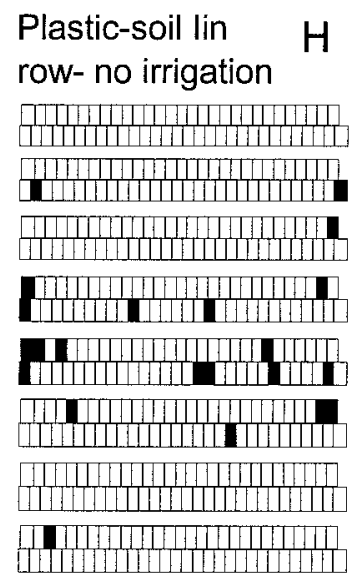

\section{Diseased $\quad \square \quad$ Healthy $\square \quad$ No plant}

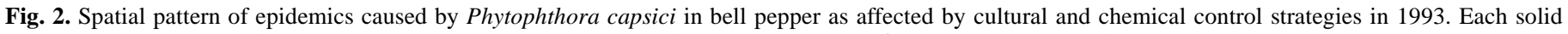

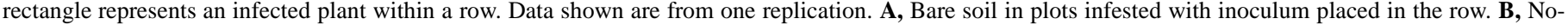

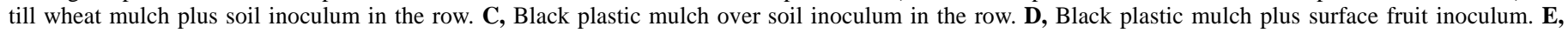

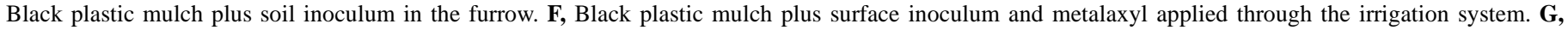
Black plastic mulch and no inoculum. H, Black plastic mulch over soil inoculum and no irrigation. 
stubble in 1993 (Fig. 2B). In 1994, final disease incidence was $43 \%$ with the use of a cover crop of wheat (Fig. 1B). However, in 1994, pathogen spread occurred from the initial point of infestation primarily down rows 4 and 5 in plots with the wheat stubble; limited across-row spread of disease occurred. Repeated measures analysis of variance indicated significant treatment $\times$ time interactions for total disease incidence in both years (Table 1).

In contrast, final disease incidence was $72 \%$ in 1993 (Fig. 1A) and $71 \%$ in 1994 (Fig. 1B), respectively, when all mechanisms of dispersal were operative in plants grown in bare soil plots. Final incidence of crown (Fig. 3B) and stem infections (Fig. 3C) were greater $(P<0.001)$ with plants grown in infested bare soil than in other plots in 1993. Final incidence of dead plants was signifi- cantly greater with plants grown in infested bare soil (Fig. 4B) than in other treatments in 1994. Pathogen spread was greatest in bare soil and occurred both within and across rows from the initial point source of infestation in rows 4 and 5 throughout the eightdouble-row plots in 1993 (Fig. 2) and 1994.

Final disease incidence was $42 \%$ in 1993 (Fig. 1A) and 78\% in 1994 (Fig. 1B), respectively, and epidemic onset began when diseased fruit was placed on the surface of plastic mulch, which allowed dispersal of inoculum by surface water and splash dispersal to operate. Plants in these plots developed crown lesions early in the epidemic in 1993 (Fig. 3B) and 1994 (Fig. 4B), and incidence of crown infections was greatest in these plots at the end of the season in 1994. Temporal development of stem infections in 1993
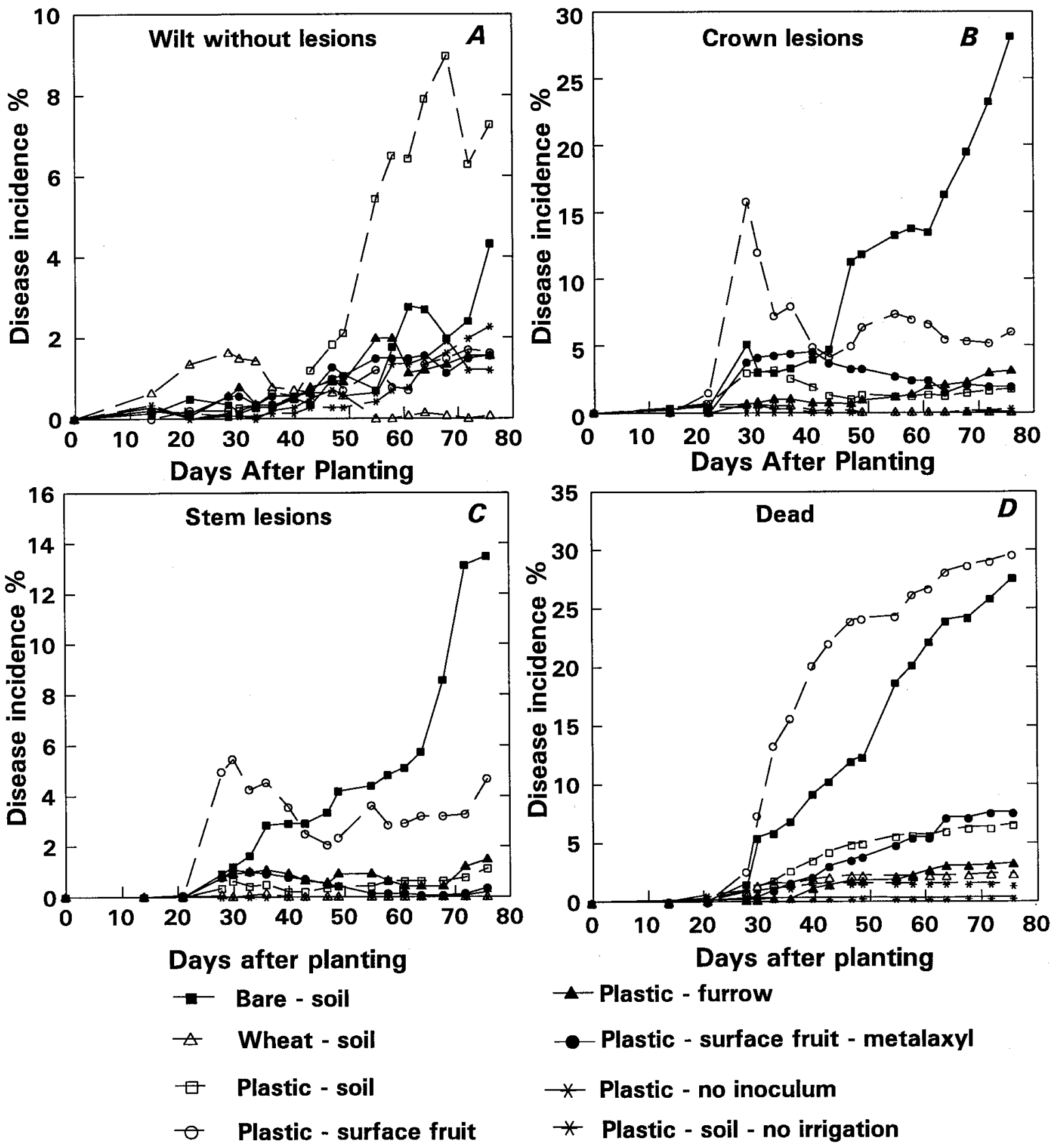

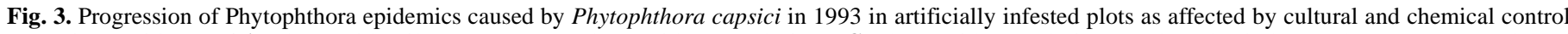
strategies. Incidence of $\mathbf{A}$, plants with wilt symptoms; $\mathbf{B}$, plants with crown lesions; $\mathbf{C}$, plants with stem lesions; and $\mathbf{D}$, dead plants. Plants were transplanted into bare soil, wheat stubble, or black plastic. Three methods of inoculation included soil in the row for which inoculum of $P$. capsici was buried approximately $10 \mathrm{~cm}$ below the soil surface in rows 4 and 5 of eight-double-row plots in the transplant hole; soil in the furrow for which inoculum was buried in the furrows adjacent to each of rows 4 and 5; or surface fruit (a sporulating pepper fruit) was placed on the top of the soil surface. 
(Fig. 3C) and 1994 (Fig. 4C) closely paralleled the temporal development of crown infections in 1993 (Fig. 3B) and 1994 (Fig. 4B) for plants grown in plastic mulch with fruit inoculum placed on the mulch surface and in infested bare soil. A large amount of spread of the pathogen within and across rows also was observed in plots with fruit inoculum on the surface of the plastic (Fig. 2D).

Disease incidence was $16.9 \%$ in plants grown in plots with plastic mulch over infested soil in 1993 (Fig. 1A). These plants also wilted earlier and had the greatest incidence of wilt at the end of the season, indicating that root infections from pathogen spread through soil within rows was the predominant dispersal mechanism (Fig. 3A). Little across-row spread of disease was evident in plots with plastic mulch over soil inoculum in 1993 (Fig. 2C). Final disease incidence was $51 \%$ in plants grown with plastic over infested soil in 1994 (Fig. 1B). These plants also had a high incidence of plants with crown (Fig. 4B) and stem lesions (Fig. 4C) at the end of the season, and some across-row spread of the pathogen was apparent.

The fungicide metalaxyl, which applied through the irrigation system, reduced disease incidence to $11.5 \%$ in 1993 (Fig. 1A) and $14 \%$ in 1994 (Fig. 1B). Dispersal of inoculum in surface water occurred in metalaxyl-treated plots, and pathogen spread within rows with subsequent disease was apparent when infected fruit were placed on the plastic. Metalaxyl, however, effectively suppressed across-row spread of the pathogen and subsequent devel-
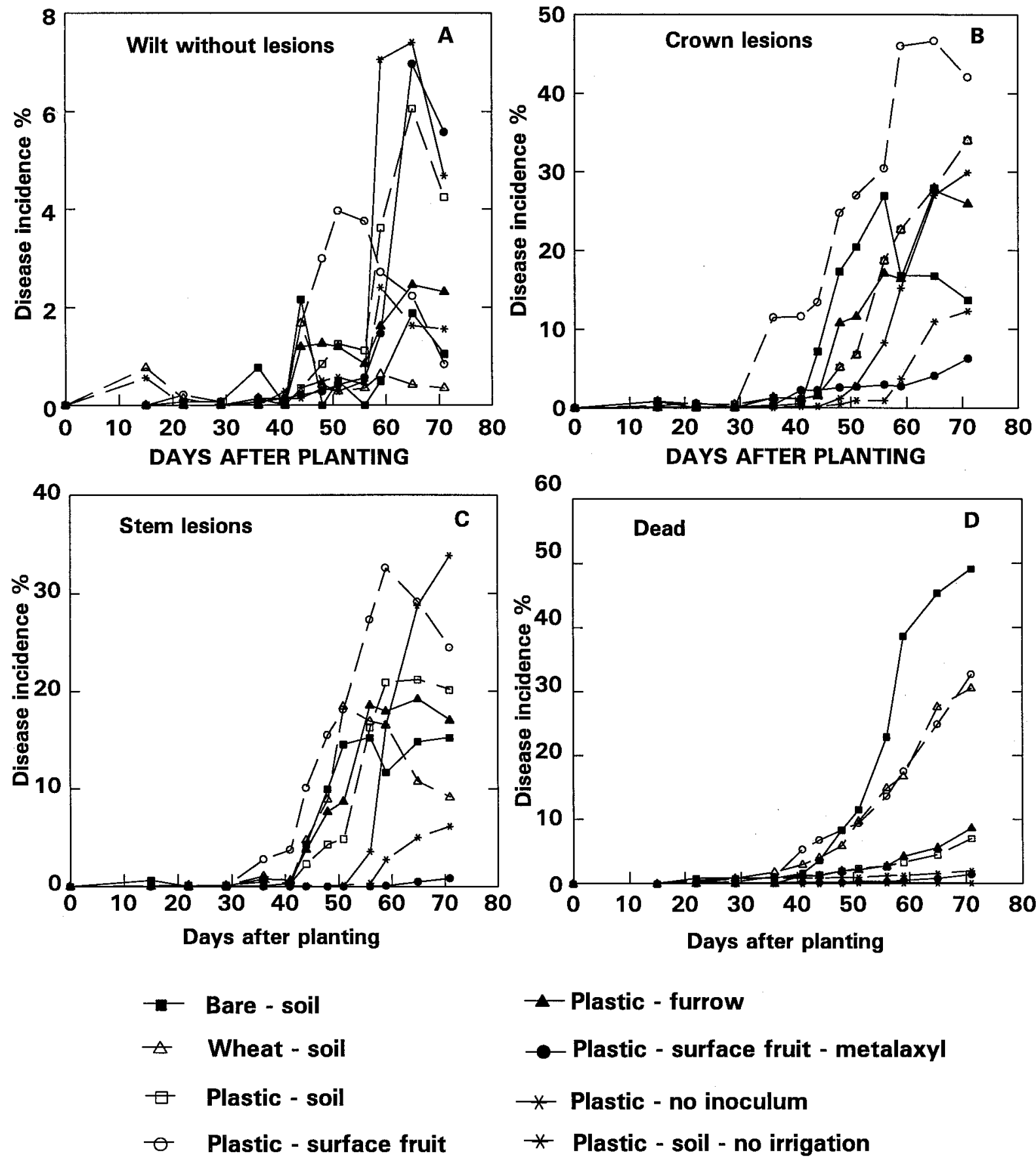

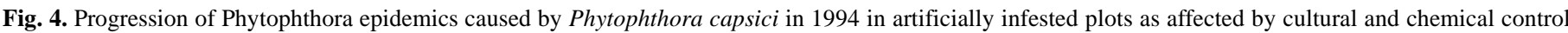

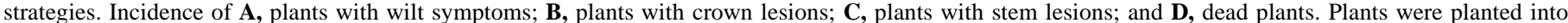

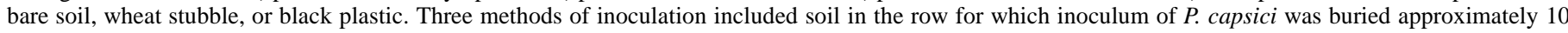

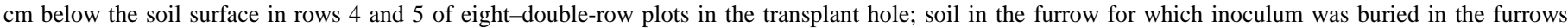
adjacent to each of rows 4 and 5; or surface fruit (a sporulating pepper fruit) was placed on the top of the soil surface. 
opment of disease (Fig. 2F). In 1994, the incidence of wilted plants without lesions was greatest in metalaxyl-treated plots, indicating that root infections occurred (Fig. 4A).

Disease incidence was $9.6 \%$ in 1993 in beds mulched with plastic and inoculum placed in the furrows (Fig. 1A). In addition, incidence of crown (Fig. 3B) and stem infections (Fig. 3C) was greater than in noninfested controls in 1993. Pathogen spread occurred primarily to plants within rows that were adjacent to the infested furrows in 1993 (Fig. 2E). Final disease incidence was $39 \%$ in plastic-covered plots infested in the furrows in 1994 (Fig. 1B), and pathogen spread occurred across rows; spread was not confined to rows adjacent to the infested furrows as in 1993. Little disease occurred in noninfested plots or nonirrigated plots in 1993 (Figs. 1 and $2 \mathrm{G}$ and $\mathrm{H}$ ). Leaf and fruit lesions were not observed in any plots in 1993. Final disease incidence was $39 \%$ in initially noninfested plots and 17\% in nonirrigated plots in 1994 (Fig. 1B). The final incidence of stem infections (Fig. 4C) was greatest in initially noninfested plots in 1994, indicating that splash and aerial dispersal of inoculum had occurred between plots in the field. Leaf infections were also more common in the 1994 than in the 1993 field tests; however, final incidence was only $6 \%$ in infested bare soil plots where leaves contacted the soil surface.

Yields of bell pepper were affected by treatment in $1993(P<$ 0.001 ). Yields were significantly greater in noninfested, metalaxyltreated, and furrow-inoculated plots than in inoculated bare soil and nonirrigated plots in 1993 (Fig. 5A). Yields were also affected by row $(P<0.01)$ in the eight-double-row plots in 1993 with lowest mean yields in rows 4 and 5, which were the rows initially infested with the pathogen (Fig. 5A). Highest average yields in 1994 occurred in noninfested plots with plastic mulch, metalaxyltreated plots, and nonirrigated plots (Fig. 5B). Yields were

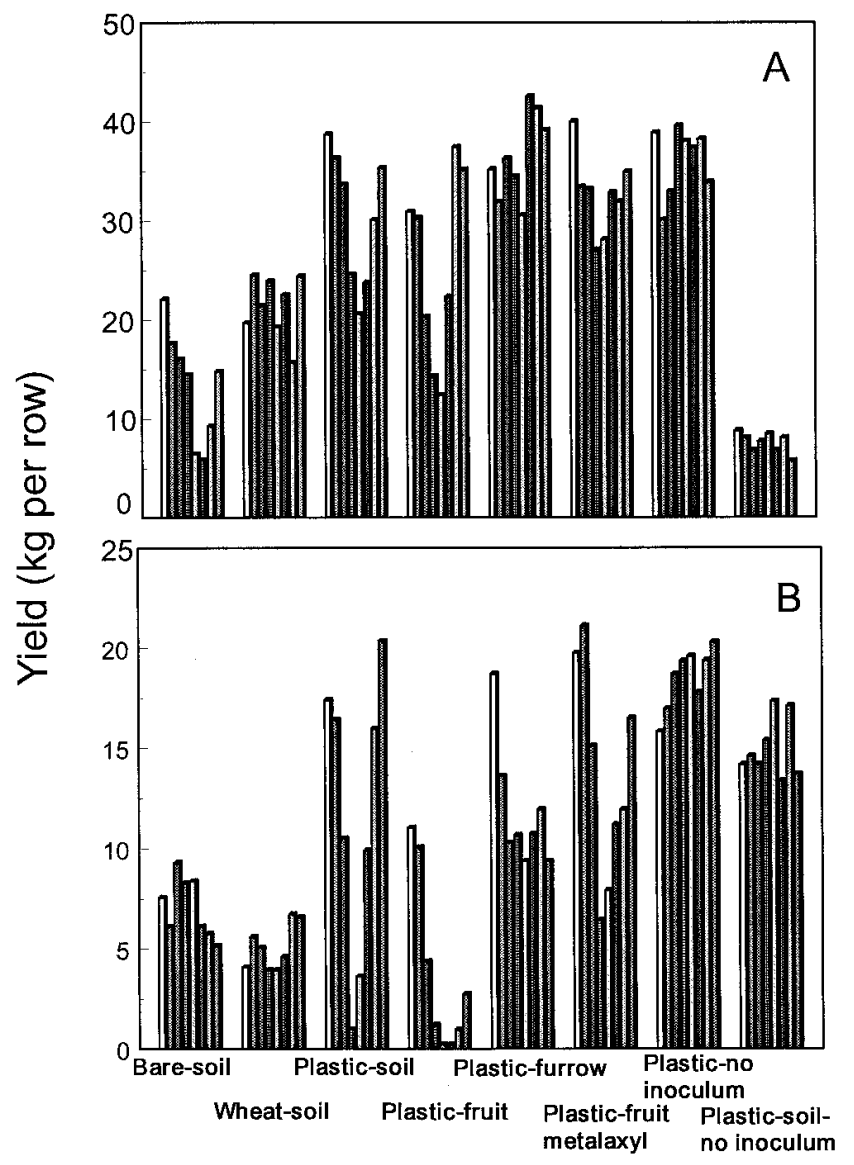

Fig. 5. Average yield of harvested fruit (kilograms of pepper) per row in each of eight treatments in A, 1993 and B, 1994. A total of eight rows were evaluated for each soil cover, inoculum, and fungicide combination. significantly lower in infested plots on bare soil, in wheat stubble plots, and in plastic-covered plots with surface inoculum than in metalaxyl-treated and noninfested plots in 1994 (Fig. 5B). In 1994, yields varied by treatment and row $(P<0.01)$. In bare soil plots inoculated in the row, yields were lowest in initially infested rows 4 and 5, whereas, in most plastic-covered plots, yield tended to decrease from left to right across rows in the plots, indicating directional spread of inoculum with several windblown rain events (Fig. 5B).

In 1993, inoculum levels of $P$. capsici in soil were greater at the first sample time in infested rows 4 and 5 (i.e., at the sites of infestation) (Table 2). Initial inoculum levels ranged from $2.5 \times 10^{3}$ to $1.1 \times 10^{4} \mathrm{CFUs}$ per gram of dry soil in 1993 . The pathogen was not present at the 3-, 6-, or 9-m sample locations down the rows at the first sample time (treatment $\times$ location effect significant at $P=$ 0.001). No treatment differences in population densities of $P$. capsici were observed at the midseason sample time, and population densities decreased over time at the site of inoculation. Treatment effects were significant $(P=0.03)$ and inoculum levels were greatest at the final sample time in bare soil plots. Row and location effects were not significant. Inoculum was not readily detected in soil around dead plants.

In 1994, inoculum levels ranged from 1.4 to $2.7 \times 10^{3}$ CFUs per gram of dry soil at the initial sample time, and no inoculum was detected at the 3-, 6-, or 9-m locations down the row (treatment $\times$ location effect significant at $P=0.001$ ) (Table 2). Inoculum densities in soil were greatest in the plots inoculated by a surface fruit placed on black plastic and in the bare soil plots at the midseason sample time (treatment effect significant at $P=0.008$ ). At harvest, there were no differences in inoculum densities in soil among treatments.

Rainfall differed between years of the study. In 1993, $33.79 \mathrm{~cm}$ of total rainfall occurred. Approximately 2.85, 6.04, and $24.9 \mathrm{~cm}$ of rainfall occurred in May to July, respectively. However, the greatest amount of rainfall in a given rainfall event occurred in July, approximately 73 to 75 days after planting in 1993 (arrows in Fig. 1A). In 1994, $23.2 \mathrm{~cm}$ of rainfall occurred in the field. Approximately $1.6,18$, and $3.6 \mathrm{~cm}$ of rainfall occurred in May to July, respectively. However, unlike the previous year, most of the rainfall events of greatest amount occurred in June, approximately 28 to 44 days after planting (arrows in Fig. 1B).

TABLE 2. Inoculum densities of Phytophthora capsici in soil at the time of inoculation, midseason, and at harvest in plants that were transplanted into bare soil, wheat stubble, or black plastic and inoculated with soil in the row, in the furrow, or with fruit inoculum placed on the mulch surface

\begin{tabular}{|c|c|c|c|c|c|c|}
\hline \multirow[b]{3}{*}{ Treatment $^{\mathrm{a}}$} & \multicolumn{6}{|c|}{ CFUs per gram of soil } \\
\hline & \multicolumn{3}{|c|}{1993} & \multicolumn{3}{|c|}{1994} \\
\hline & Early $^{\mathrm{b}}$ & Mid & Late & Early ${ }^{b}$ & Mid & Late \\
\hline Bare soil & 8,511 & 31.40 & 12.50 & 2,744 & 5.05 & 2.50 \\
\hline Wheat-soil & 11,683 & 0.20 & 0.24 & 2,319 & 0.67 & 1.50 \\
\hline Plastic-soil & 5,715 & 1.30 & 2.91 & 2,666 & 5.34 & 1.80 \\
\hline Plastic-surface fruit & 0 & 1.00 & 1.28 & 0 & 8.07 & 0.05 \\
\hline Plastic-furrow & 2,529 & 0.50 & 0.89 & 1,415 & 0.95 & 0.47 \\
\hline $\begin{array}{l}\text { Plastic-surface fruit- } \\
\text { metalaxyl }\end{array}$ & 0 & 0.21 & 0.29 & 0 & 0.04 & 2.55 \\
\hline $\begin{array}{l}\text { Plastic-no inoculum } \\
\text { Plastic-soil- }\end{array}$ & 0 & 0.02 & 0.14 & 0 & 0.25 & 0.53 \\
\hline no irrigation & 10,023 & 0.33 & 0.56 & 2,760 & 0.07 & 0.42 \\
\hline
\end{tabular}

a Plants were planted into bare soil, wheat stubble from a fall-sown cover crop, or black plastic. Three methods of inoculation included soil in the row for which inoculum of $P$. capsici was buried approximately $10 \mathrm{~cm}$ below the soil surface in rows 4 and 5 of eight-double-row plots in the transplant hole; soil in the furrow for which inoculum was buried in the furrows adjacent to each of rows 4 and 5; or surface fruit (a sporulating pepper fruit) was placed on the top of the soil surface.

b Treatment $\times$ location effect was significant and means are shown from the site of inoculation in rows 4 and 5 from each treatment and furrows in plastic-furrow treatment. 


\section{DISCUSSION}

We have demonstrated that specific modifications in pathogen dispersal mechanisms via changes in cultural practices can have significant impacts on both the spatial and temporal components of epidemic development. Differential placement of inoculum, various soil cover treatments, and the use of metalaxyl were apparently effective in achieving the hypothesized alterations of inoculum dispersal mechanisms. Some of these factors also represent practical cultural practices for grower use in the field. The most striking finding from our research was that planting a pepper crop into stubble from a no-till wheat cover crop significantly suppressed dispersal of inoculum and subsequent disease occurrence.

The no-till system used in our study left residues that covered most of the soil surface, and these residues provided an effective barrier to inoculum dispersal. The mechanism of suppression of disease in the no-till system may, thus, involve a simple reduction in splash dispersal of surface inoculum to aboveground parts of plants. No-till systems can reduce runoff of surface water by 86.3 to $98.7 \%$ (12), and movement in surface water is the primary method of inoculum dispersal of $P$. capsici in agricultural fields $(24,25)$. Movement of inoculum within the soil also may have been reduced in the no-till plots. Inoculum densities at harvest in both years were greatest in the soil when disease incidence was greatest (i.e., the bare soil plots in 1993 and 1994). Soil bulk density may have been greater and air-filled porosity lower in the notill plots (12), and these factors may have contributed to reduced pathogen movement in the soil. These results, however, cannot rule out other mechanisms of pathogen or disease suppression within the no-till, wheat stubble treatment. For example, decomposing wheat roots are known to produce toxins that can be suppressive to soilborne pathogens $(5,30)$. Soil biological communities that may be involved in suppression of disease are generally more diverse in no-till than in conventional-tilled soil and are related closely to the organic matter distribution (29). The cover crop may have had an indirect effect on host plant susceptibility to $P$. capsici, since nitrogen levels may have been lower in plants grown in the cover crop plots. In addition to the benefits of reduced wind and water erosion from minimum tillage systems, reduced spread of an important pathogen, $P$. capsici, was obtained in our study. In some pathosystems, no-till systems may be detrimental to crops, because increased pathogen survival in the plant debris has been reported $(1,9,30)$, and further studies on this possibility with $P$. capsici are warranted.

Surface-applied straw mulch has been used as a ground cover to suppress splash dispersal of $P$. cactorum in strawberry fields (15). Incidence of diseased strawberry fruit was $80 \%$ on plastic- and $15 \%$ on straw-covered soil at high rain intensities and duration (15). In our study, we grew the cover crop the previous fall and left the stubble in place during crop growth, in contrast to surfaceapplied straw mulch. It is likely that surface-applied mulch would also suppress dispersal of inoculum of $P$. capsici, but we have not evaluated this method in field studies with pepper plants. In our study, the fall-sown cover crop was mowed and sprayed with herbicide in the spring. We know that the herbicide paraquat was not suppressive to disease, since disease spread occurred in 1994 and in other greenhouse trials (data not shown).

The dynamics of occurrence of several types of symptoms also allowed us to confirm the importance of specific dispersal mechanisms in the $P$. capsici-pepper pathosystem. The temporal dynamics of disease increase on stems closely paralleled the temporal dynamics of disease increase on crowns in both years. These results confirm our observations from grower fields on the spatial dynamics of stem infections and indicate that splash dispersal to stems from surface inoculum can be important in epidemic development (25).

In metalaxyl-treated plots, splash dispersal of propagules to foliar plant parts, particularly across rows, rarely resulted in suc- cessful infections. Within-row spread of disease was apparent in infested plots treated with metalaxyl through the drip system, but across-row spread was limited. Our data provide new information of the "mode of action" of the fungicide metalaxyl in the field. Because the fungicide is transported upward systemically in the plant from roots to leaves, protection of aboveground portions of the plant from splash-dispersed inoculum was apparently more effective than protection of roots and crowns of plants near the soil. In addition, in 1993, the importance of pathogen spread through soil and subsequent root infection in the metalaxyl-treated plots was confirmed by the presence of a greater number of wilted plants without stem lesions in plants in this treatment.

Yields were not as great in no-till plots as in plots treated with metalaxyl in both years. This may have been due to the inadequacy of nitrogen available to the pepper crop following the wheat crop. Fertilizer applied to the surface of the no-till plots may have been immobilized because of the accumulation of decomposing residues (30). In studies conducted in 1995 and 1996, we used a rye-vetch no-till cover crop with a zone tillage method to reduce soil compaction in the root zone and obtained significant disease suppression and improved yields (J. B. Ristaino, G. Parra, and C. L. Campbell, unpublished data). The no-till cover crop was less effective in suppression of disease in our studies in 1994 than in 1993. The timing of early rainfall events in 1994 may have led to more splash dispersal of inoculum than there was in the previous year. The incidence of stem and leaf lesions were also greater in 1994 than in 1993, indicating that aerial dispersal of inoculum across rows was of greater importance in 1994.

Growers in the United States routinely use black plastic mulch and soil fumigation with methyl bromide for vegetable production systems. Our data indicate that spread of $P$. capsici occurs rapidly on the surface of plastic mulch and leads to increased disease incidence compared with that obtained with the alternative, no-till system. Fumigation of soil with methyl bromide will soon no longer be an option for vegetable growers in the United States as a result of the Montreal protocol (4). No single chemical alternative is available that will replace methyl bromide for control of soilborne pathogens in vegetable production systems (4). However, alternatives such as the no-till cover crop method described here can provide a viable option for reducing the impact of diseases caused by Phytophthora spp.

\section{ACKNOWLEDGMENTS}

This research was funded, in part, by grant 92-37303-7715 from the National Research Initiatives Competitive Grants Program, United States Department of Agriculture. We thank R. Larkin, M. Gumpertz, and C. Harper for their assistance.

\section{LITERATURE CITED}

1. Abelson, P. A. 1995. Plant pathogens in soil. Science 270:1027.

2. Anonymous. 1989. Alternative Agriculture. National Academy Press, Washington, DC.

3. Anonymous. 1993. Pesticides in the Diets of Infants and Children. National Academy Press, Washington, DC.

4. Anonymous. 1993. Proceedings from the USDA Workshop on Alternatives to Methyl Bromide. U.S. Department of Agriculture, Washington, DC.

5. Blum, U. 1996. Allelopathic interactions involving phenolic acids. J. Nematol. 28:259-267.

6. Bowers, J. H., Sonoda, R. M., and Mitchell, D. J. 1990. Path coefficient analysis of the effect of rainfall variables on the epidemiology of Phytophthora blight of pepper caused by Phytophthora capsici. Phytopathology 80:1439-1446.

7. Café-Filho, A. C., and Duniway, J. M. 1995. Effects of furrow irrigation schedules and host genotype on Phytophthora root rot of pepper. Plant Dis. 79:39-43

8. Campbell, C. L., Jacobi, W. R., Powell, N. T., and Main, C. E. 1984. Analysis of disease progression and the randomness of occurrence of infected plants during tobacco black shank epidemics. Phytopathology 74:230-235. 
9. Cook, R. J. 1991. Challenges and rewards of sustainable agriculture research and education. Pages 32-76 in: Sustainable Agriculture Research and Education in the Field: A Proceedings. T. Hullar, ed. National Academy Press, Washington, DC.

10. Fraser, D. E., Shoemaker, P. B., and Ristaino, J. B. 1995. Characterization of Phytophthora infestans isolates from tomato and potato in North Carolina, USA, 1993-1995. Pages 102-106 in: Proceedings of the Phytophthora 150 Conference, Boole Press, Ltd., Dublin.

11. Fry, W. E. 1978. Quantification of general resistance of potato cultivars and fungicide effects for integrated control of potato late blight. Phytopathology 68:1650-1655.

12. Griffith, D. R., Mannering, J. V., and Box, J. E. 1986. Soil and moisture management with reduced tillage. Pages 19-58 in: No-Tillage and Surface-Tillage Agriculture: The Tillage Revolution. M. A. Sprague and G. B. Triplett, eds. John Wiley \& Sons, New York.

13. Larkin, R. S., Gumpertz, M. L., and Ristaino, J. B. 1995. Geostatistical analysis of Phytophthora epidemics in commercial bell pepper fields. Phytopathology 84:191-203.

14. Lucas, J. A., Shattock, R. C., Shaw, D. S., and Cooke, L. R. 1989. Phytophthora. Cambridge University Press, Cambridge.

15. Madden, L. V., and Ellis, M. A. 1990. Effect of ground cover on splash dispersal of Phytophthora cactorum from strawberry fruits. J. Phytopathol. 129:170-174.

16. Masago, H., Yoshikawa, M., Fukada, M., and Nakanishi, N. 1977. Selective inhibition of Pythium spp. on a medium for direct isolation of Phytophthora spp. from soils and plants. Phytopathology 67:425-428.

17. Milgroom, M. E., Levin, S. A., and Fry, W. E. 1989. Population genetics theory and fungicide resistance. Pages 340-367 in: Plant Disease Epidemiology: Genetics, Resistance, and Management. K. J. Leonard and W. E. Fry, eds. McGraw-Hill, New York.

18. Neher, D., and Duniway, J. M. 1992. Dispersal of Phytophthora parasitica in tomato fields by furrow irrigation. Plant Dis. 76:582-586.

19. Reynolds, K. M., and Madden, L. V. 1988. Analysis of epidemics using spatio-temporal autocorrelation. Phytopathology 78:240-246.

20. Reynolds, K. M., Madden, L. V., and Ellis, M. A. 1988. Spatio-temporal analysis of epidemic development of leather rot of strawberry. Phytopathology 78:246-252.
21. Ristaino, J. B. 1991. Influence of rainfall, drip irrigation, and inoculum density on the development of Phytophthora root and crown rot epidemics and yield in bell pepper. Phytopathology 81:922-929.

22. Ristaino, J. B., Duniway, J. M., and Marois, J. J. 1988. Influence of frequency and duration of furrow irrigation on the development of Phytophthora root rot and yield in processing tomatoes. Phytopathology 78:1701-1706.

23. Ristaino, J. B., Hord, M. J., and Gumpertz, M. L. 1992. Population densities of Phytophthora capsici in field soils in relation to drip irrigation, rainfall, and disease incidence. Plant Dis. 76:1017-1024.

24. Ristaino, J. B., Larkin, R. P., and Campbell, C. L. 1993. Spatial and temporal dynamics of Phytophthora epidemics in commercial bell pepper fields. Phytopathology 83:1312-1320.

25. Ristaino, J. B., Larkin, R. P., and Campbell, C. L. 1994. Spatial dynamics of disease symptom expression during Phytophthora epidemics in bell pepper. Phytopathology 84:1015-1024.

26. Ristaino, J. B., Parra, G., and Campbell, C. L. 1994. Dispersal of Phytophthora capsici in bell pepper suppressed by a no-till wheat cover crop. (Abstr.) Phytopathology 84:1080.

27. Schlub, R. L. 1983. Epidemiology of Phytophthora capsici on bell pepper. J. Agric. Sci. 100:7-11.

28. Shew, H. D. 1987. Effect of host resistance on spread of Phytophthora parasitica var. nicotianae and subsequent development of tobacco black shank under field conditions. Phytopathology 77:1090-1093.

29. Smith, M. S., and Rice, C. W. 1983. Soil biology and biochemical nitrogen transformations in no-tilled soils. Pages 215-226 in: Environmentally Sound Agriculture. W. Lockeretz, ed. Praeger Special Studies, New York.

30. Sumner, D. R., Threadgill, E. D., Smittle, D. A., Phatak, S. C., and Johnson, A. W. 1986. Conservation tillage and vegetable diseases. Plant Dis. 70:906-911.

31. Umaerus, V., Umaerus, M., Erjefalf, L., and Nilsson, B. A. 1983. Control of Phytophthora by host resistance: Problems and progress. Pages 315326 in: Phytophthora: Its Biology, Taxonomy, Ecology, and Pathology. D. C. Erwin, S. Bartnicki-Garcia, and P. H. Tsao, eds. The American Phytopathological Society, St. Paul, MN.

32. van der Plank, J. E. 1963. Plant Diseases: Epidemics and Control. Academic Press, New York. 